\title{
Concentration in Knowledge Output: A case of Economics Journals
}

\author{
Paul Gopuran Devassy Bino ${ }^{\mathrm{a}}$, Sasidharan. Subash ${ }^{\mathrm{b}}$, Ananthakrishnan \\ Ramanathan ${ }^{\mathrm{b}}$ \\ ${ }^{a}$ TA Pai Management Institute, Manipal - ${ }^{\mathrm{b}}$ Indian Institute of Technology, Bombay
}

\begin{abstract}
This paper assesses the degree of author concentration in seven economics journals, which were published in India during 1990-2002. To measure the degree of author concentration, Lotka's Law was used. Moreover, we also make an exploratory analysis of the geographic, economics subfield and institutional concentration in 704 economics journals. An important finding of this paper is that specialized journals in the sample report the highest degree of author concentration. This result is quite similar to the findings by Cox and Chung (1991). Furthermore, there are several instances showing that the journals lean towards certain norms; this may affect the flow of innovative ideas into economics. We conclude that a knowledge activity, involving the high degree of concentration and a biased publication process, may affect the flow of new ideas into the discipline.
\end{abstract}

JEL Classification: A14, B50, B52

Keywords: Concentration, Lotka’s Law

\section{Introduction}

This paper examines the degree of concentration that exists in the distribution of knowledge output among individuals. The analysis is based on seven economics journals, which were published in India during 1990-2002. It also gives an analysis of macro units of concentration such as geography, area and institution; for this purpose it covers 704 economics journals. Further, we discuss some aspects of the publication process, and explore how it affects the discipline. The analytic approach in this paper is of a mixed type. Lotka's Law, following Cox and Chung (1991), is applied to the author data, while simple measures like the Herfindahl-Hirschman Index (HHI) and the share of top three institutions are used as the measures for the other units of concentration.

Journals, in any academic discipline, play a crucial role by facilitating the exchange of knowledge, and thereby contributing to the overall expansion of knowledge. An article, published in a journal, is often referred to as an item of knowledge output (Lovell, 1973); it provides a variety of benefits to its author. Naturally, a typical researcher will try to publish her papers in reputed journals. It is quite likely that there is an excess demand for such opportunities. The degree of scarcity is more severe in the prestigious journals. Unlike simple market clearing, the exchange between authors and a journal is more complex. In such an exchange, norms play a significant role. Each journal has its own norms. However, a few norms such as the degree of formalism are common across economics journals. ${ }^{1}$ Moreover, the decisions by a journal's editors and referees are often sensitive to such norms. The norms, which the journals adopt, have specific cultural contexts. In many instances, the norms evolve in the universities and schools of thought, and later the journals adopt them. Reflecting

\footnotetext{
${ }^{1}$ See Ellison $\left(2002_{\mathrm{b}}\right)$ for a discussion on norms.
} 
on this cue, we can say that such institutions have a role in the publication process. An author has to comply with the norms for getting her article published while many lack the skills to fulfill them. The institutions often act as the conduits through which the authors get acquaintance with these norms. ${ }^{2}$ Such norms often constrain the chances of an author, who is less familiar with the skills specific to these norms, from publishing her article. It is quite likely that the authors from the institutions, which have expertise in such skills, tend to have more publications.

The contents of this paper are as follows: Section 2 deals with the concentration in knowledge output. Section 3 covers the analysis of different concentration indicators. Section 4 discusses the issues related to the publication process. Section 5 concludes the paper.

\section{Concentration in Knowledge Output}

The knowledge output in economics has shown significant growth in recent times. One fourth of Social Science publications are in economics; it gets one third of the citations in Social Science (Ingwersen et al., 2001). Siegfried and Stock (1999) note that economics is one of the highly paid professions. Moreover, it is the only social science, which has the Nobel Prize as the top honour for scholars. However, the concentration in the knowledge output is a salient feature of economics journals (Hodgson and Rothman, 1999). On the issues related to this, quite a number of articles have been published (Table A1, Appendix). It is apparent from the studies that a few American institutions (e.g. Harvard, Stanford, MIT, Chicago, Yale etc.) occupy the top of the institutional order. Furthermore, Hodgson and Rothman (1999) bring out the issue of 'institutional oligopoly in journals'. They say:

Overall, strong evidence has been presented of the domination of journal articles and editorships in economics by just a few U.S. academic institutions. Clearly, this evidence raises disturbing questions about the existence of an 'oligopoly' of U.S. institutions dominating leading journals in economics and economics research throughout the world... There is strong evidence here of the domination of publications in 30 leading economics journals by authors coming from, or located in, relatively few U.S. academic institutions. ( $p$ 172-174)

The authors identify the following reasons for the issue: editorial favouritism, path dependent processes, and increasing language compatibility within the institutions. As observed by them, the editorial favouritism does not adequately explain the concentration. However, Laband and Piette (1994) find editorial favouritism as a significant determinant of citation. ${ }^{3}$ The second factor, 'path dependence', refers to the long survival of an institutional order, which has a few institutions at the top. If such a situation prevails, the journals may tend to show resistance to new ideas. Hodgson and Rothman (1999) reflect their concern about this issue:

\footnotetext{
2 Doctoral training is an example for this.

${ }^{3}$ Laband and Piette (1994) specified citation as function of characteristics of journal, gender, authoreditor institutional connection and authors stock of citation (see Laband and Piette (1994), p.197 equation 1).
} 
The danger with such a high degree of institutional concentration in the editors and authors of journals as is evidenced by the 1995 data is that it may be difficult for further change to take place. 'Lock-in' may occur, where specific institutions defend specific, and possibly outdated, ideas and approaches. In these circumstances, it would be quite difficult for alternative or innovative approaches to establish themselves. ( $p$ 182)

The third factor denotes that the institutions and journals agree on certain theoretical and methodological assumptions as the norms for publishing the articles. For instance, it is known that most of the institutions and journals agree on using the neoclassical models as the theoretical frame. Besides, there seems to be lesser disagreement among the institutions on the norms such as the degree of formalism. An appropriate proxy, for this factor, may be the trend towards increasing use of mathematics in economics (Stigler et al., 1995). ${ }^{4}$

\section{Analysis of Concentration Indicators}

\subsection{Economics field, Geographic and Institutional Concentration}

The present analysis covers 704 journals. There are three units of analysis, namely area, geography, and institution; they represent the sub-field in economics, the region, and the university, respectively. The data is obtained from a website. ${ }^{5}$

Herfindahl-Hirschman Index (HHI) has been computed to measure the area and geographic concentration. According to Hirschman (1964), HHI can be used for measuring concentration in an industry; it is the sum of squared market shares. The index may be expressed as:

$$
H H I=\sum_{i=1}^{n}\left(M S_{i}\right)^{2}
$$

Where $M S_{i}$ represents the market share (in per cent) of firm $i$, and there are $n$ firms in the market. ${ }^{6}$ The distribution of journals over 19 subfields is given in table A2 (Appendix). Geographic distribution consists of nine regions. ${ }^{7}$

HHI values are classified into three categories: unconcentrated (HHI below 1000), moderately concentrated (HHI between 1000 and 1800), and highly concentrated (HHI above 1800). ${ }^{8}$ The results are presented in Table 1.

\footnotetext{
${ }^{4}$ As regards the technical content in journal articles, as shown by Stigler et al. (1995), mathematics has clear dominance over the natural language such as English.

5 <http://homepages.ulb.ac.be/ tcoupe/ranking.html>

${ }^{6}$ The HHI takes into account the relative size and distribution of the firms in a market; it approaches zero when a market consists of a large number of firms of relatively equal size. The HHI increases both as the number of firms in the market decreases and as the disparity in size between those firms increases.

7 The regions are Asia, Africa, Canada, European Union, Ex-USSR, Latin America, Middle East, Oceania, and USA (http://homepages.ulb.ac.be/ tcoupe/ranking.html).

8 The U.S. Department of Justice and the Federal Trade Commission (1992) use this classification for measuring the degree of concentration in the market.
} 
EJCE, vol. 2, n. 2 (2005)

Table 1. Economics field, Geographic and Institutional Concentration

\begin{tabular}{|c|c|c|c|c|}
\hline \multicolumn{5}{|c|}{ Economics field and Geographic Concentration } \\
\hline \multicolumn{5}{|c|}{ Economics field (based on JEL classification) } \\
\hline $\mathrm{HHI}$ & Number $(\mathrm{N}=704)$ & Percent & Mean & $\begin{array}{c}\text { Standard } \\
\text { Deviation }\end{array}$ \\
\hline$<1000$ & 34 & 4.8 & 904.9 & 59.0 \\
\hline $1000-1800$ & 193 & 27.4 & 1343.3 & 220.7 \\
\hline$>1800$ & 477 & 67.8 & 3924.8 & 1570.5 \\
\hline \multicolumn{5}{|l|}{ Geographic } \\
\hline$<1000$ & - & - & - & - \\
\hline $1000-1800$ & - & - & - & - \\
\hline$>1800$ & 704 & 100 & 6163.01 & 2256.44 \\
\hline \multicolumn{5}{|c|}{ Contribution of Top Three Institutions } \\
\hline & $>20 \%$ & $>40 \%$ & $>60 \%$ & $>80 \%$ \\
\hline Number of Journals & $\begin{array}{c}330 \\
(46.9)\end{array}$ & 131 & 59 & $\begin{array}{c}30 \\
(43)\end{array}$ \\
\hline
\end{tabular}

Source: Computed from <http:/ / homepages.ulb.ac.be/ tcoupe/ ranking.html>

Nearly $66 \%$ of journals report high degrees of field concentration (i.e. HHI greater than 1800). A major implication of this result is that there seems to be higher degree of specialization in the subject. However, the specialization need not imply that there is diversity in the language and methodology, which form the base for many articles in different fields. It is quite likely that competence in certain languages and methods enables a person to publish in a wide range of fields. In other words, the subject may have a variety of areas, but there is no desirable diversity in the language and methodology. Two major trends, i.e. neoclassical hegemony and mathematization of economics, seem to support this observation (Beed and Kane, 1991).

All the journals report high degrees of geographic concentration. As shown by the results, the United States of America (US) has a clear dominance over other regions in most of the journals, barring a few journals from the other regions. All the journals report HHI values greater than 1800, which implies high degree of geographic concentration; a large majority of authors in most of the journals is US based. The influx of the scholars from different countries to the US seems to be a major reason that explains the US dominance in the knowledge output (Coupe, 2001).

Since there are many institutions with small shares in knowledge output, HHI has a considerable limitation in capturing the degree of institutional concentration. ${ }^{9}$ Considering this limitation, the share of the top three institutions is taken as a measure of the institutional concentration. It can be observed from table 1 that the top three institutions for each of the 330 journals contribute more than $20 \%$ of authors. At the same time, 30 journals have more than $80 \%$ of authors, who are from the top three institutions. What emerges from the analysis is that a high degree of institutional concentration exists in a large number of journals.

There seems to be a relation between institutional concentration and geographic concentration. ${ }^{10}$ The contribution of the top three institutions and HHI represent these two variables, respectively. The following model can specify the relation:

\footnotetext{
${ }^{9}$ Especially, when the shares are less than one percent.

10 This relation satisfies the criteria such as statistical significance, no misspecification, and homoscedasticity.
} 
$\mathrm{Y}=\beta_{0}+\beta_{1} \mathrm{X}+\mathrm{u}$

$\mathrm{Y}=\mathrm{HHI}$ in respect of geographic concentration

$\mathrm{X}=$ Contribution of top three institutions

$\beta_{0}, \beta_{1}=$ Parameters, $\mathrm{u}=$ error

The OLS estimates indicate that there is a significant relation between $\mathrm{Y}$ and $\mathrm{X} .^{11}$ However, the low $\mathrm{R}^{2}$ seems to indicate the need for more explanatory variables in the model.

Table 2: Ordinary Least Square (OLS) Estimate of Equation 2

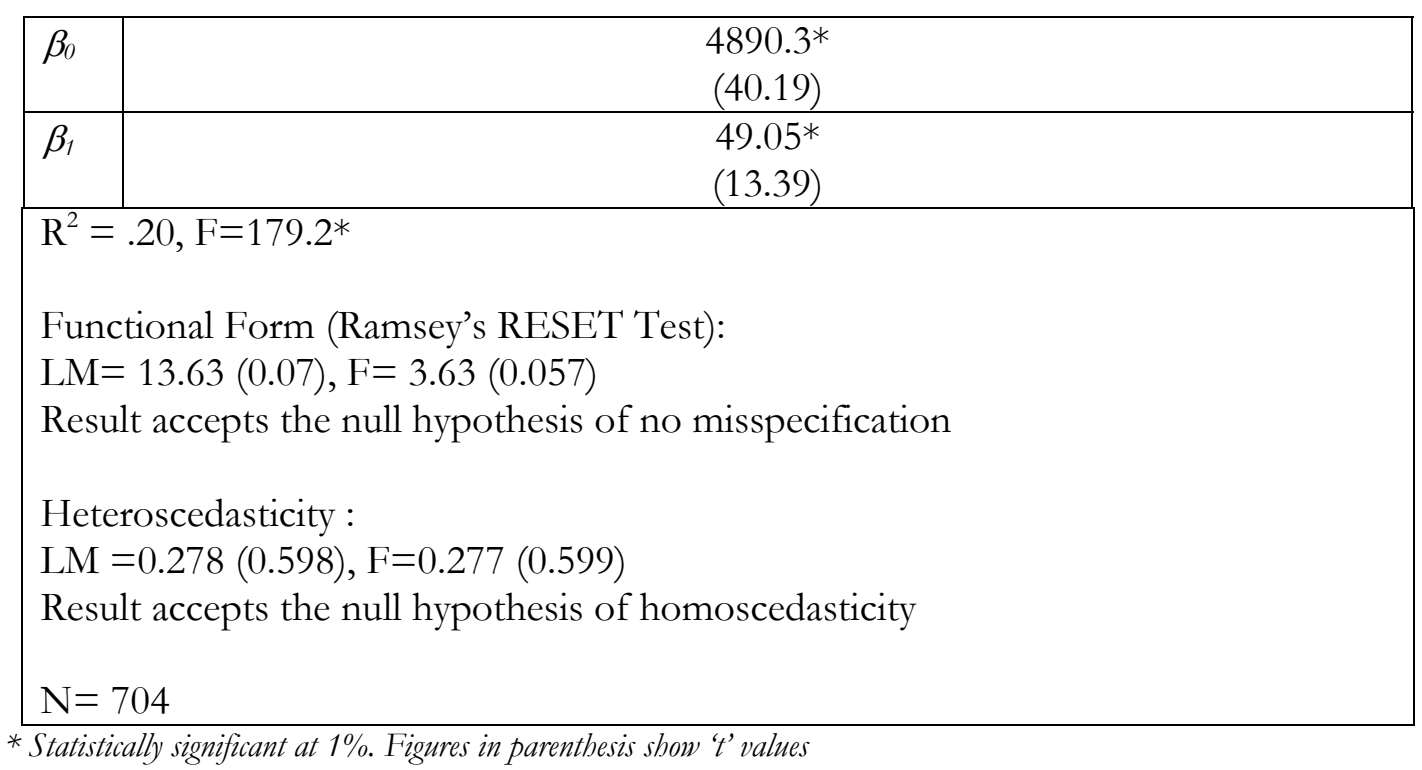

\subsection{Author Concentration}

Among the units of concentration, that of author is the most basic. It is desirable to examine the author distribution to gain some insights on the degree of concentration at the micro level. In this we make use of Lotka's Law, which is not wellknown in the economics profession and does therefore require a brief introduction.

\subsubsection{Lotka's Law}

In 1926, Alfred J. Lotka analysed the author data to study scientific productivity. ${ }^{12}$ Based on the author distribution, he came up with a law (Lotka, 1926). The law states that the number of authors producing $n$ papers relative to the number of authors producing one paper is the inverse of $n^{2}$. Lotka's Law can be stated as follows (Subramanyam, 1979; Chung and Cox, 1990; Cox and Chung, 1991):

$$
a_{n}=\frac{a_{1}}{n^{2}}, \quad n=1,2,3, \ldots \ldots
$$

\footnotetext{
11 The US has major share in most of the journals. However, a few top order institutions dominate the US pie. This function is not a redundant one, since it is quite likely to have the combinations such as high $\mathrm{Y}$ and low X.

12 Decennial index of Chemical Abstracts and name index of Auerbach's Geschichtstafeln der Physik were the sources.
} 
$a_{n}=$ Number of authors publishing $\mathrm{n}$ papers

$\mathrm{n}=$ Number of papers

This implies that for every 100 authors, who produce only one paper in a given period of time, there are 25 authors who produce two papers, and one author, who produces 10 papers. Lotka's law is often used for examining either the scientific productivity or the author concentration. Cox and Chung have used a generalized Lotka's Law (Cox and Chung, 1991), as follows:

$$
a_{n}=\frac{a_{1}}{n^{\beta}} \quad \mathrm{n}=1,2,3 \ldots \ldots
$$

where $\beta$ is a constant.

The fit of the Equation (4), for different values of $\beta$, is given in Appendix Table A3. As $\beta$ and $n$ increase, $a_{n}$ declines. An increase in $\beta$ implies a reduced author concentration. The proportion of authors with just one paper increases with an increase in $\beta$ and vice versa for a smaller $\beta$.

The procedure for testing Lotka's Law, as described by Cox and Chung (1991), requires the comparison between observed and theoretical distributions of authors over number of papers.

As specified by Cox and Chung (1991), equation (4) can be converted into the following regression model for measuring the degree of concentration:

$$
\log \left(\frac{a_{n}}{a_{1}}\right)=\beta^{*} \log n+u
$$

The negative parameter $\beta$ indicates the degree of author concentration in any given journal. We shall refer to the absolute value of $\beta$. A low $\beta$, i.e., a low $|\beta|$, implies high degree of author concentration, and vice versa.

\subsubsection{A Review of Cox and Chung (1991)}

Cox and Chung (1991) studied author distribution in the top twenty economics journals during 1963-1988. The main objective of their study was to identify the empirical regularity in the author distribution; by 'regularity', they mean the prevalence of Lotka's law in sample journals. By testing the prevalence of Lotka's Law, two results are expected: (i) likelihood of multiple publications (ii) the degree of the author concentration. Cox and Chung (1991) put:

We believe that the identification of such empirical regularities is useful, since it will help assess both the likelihood of multiple publications in the economics literature and the degree of author concentration among different journals. ( $p$ 741)

The study reports that the percentage of authors with just one paper varies from 64.9 to 81.5; the lowest and the highest figures represent the Journal of Financial Economics and the Journal of Economic Literature, respectively. Further, the journals, having a higher degree of specialization (e.g. the Journal of Financial Economics), have a higher percentages 
of authors, who have authored multiple papers. Cox and Chung perform the Chi-square goodness-of-fit test for examining if Lotka's Law applies to the data. The results show that only two out of 18 journals conform to Lotka's Law. They then use the parameter $\beta$ to measure the degree of author concentration-see equation (5). $\beta$ is the slope of regression between the logarithm of ratio of number of authors with $n$ papers to number of authors with just one paper (as dependent variable) and logarithm of number of papers (as independent variable). ${ }^{13}$ The estimated slopes vary from 2.04 to $3.11 .{ }^{14}$ Brookings Papers on Economic Activity and the Quarterly Journal of Economics report the highest and lowest concentration respectively (Table 6).

An interesting finding from the study is that journals like the Quarterly Journal of Economics, which cover general themes, show a high $\beta$, i.e., a low degree of concentration. On the other hand, the specialized journals like the Journal of Financial Economics exhibit a low $\beta$, i.e., a high degree of concentration. According to Cox and Chung, similar evidence can be found in other disciplines such as computer science and finance. ${ }^{15}$ To examine if the specialization explains the concentration, the $\beta$ s were regressed with the average number of papers the journal published per year and a dummy variable for specialization. ${ }^{16}$ The results show that the dummy variable has a negative sign and is significant at the five per cent level. Cox and Chung (1991) note:

The regression result shows that the coefficient of the dummy variable has the predicted sign and is significant at the $5 \%$ level, suggesting that the journals with specialized focus have a high author concentration. (p. 745)

Further, Cox and Chung (1991) observe that the institutional concentration is a salient feature of the journals. As noted by the authors, the top three schools produce more than half of the top 100 scholars, who contribute to the top 20 journals.

\subsubsection{A Study of Author Concentration in Seven Indian Journals}

Regional journals often have a critical role in shaping the life cycle of economists, particularly those outside the US/EU regions. It is therefore interesting to compare the Cox and Chung (1991) findings with degree of author concentration in India.

We study seven journals, which are published in India. They include the Indian Economic Review, the Indian Economic Journal, the Journal of Quantitative Economics, the Indian Economic and Social History Review, the Indian Journal of Economics, the Indian Journal of Agricultural Economics and the Artha Vijnana. These journals are published either by reputed universities (e.g. Delhi University) or by professional associations (e.g. Indian Society of Agricultural Economics). Among these journals, the Indian Journal of Agricultural Economics seems to be more specialized than the rest. ${ }^{17}$ On the other hand, most of the articles in the Indian Economic Review, the Indian Journal of Economics, the Indian Economic Journal, and the Artha Vijnana appear to be general in nature. The content in the Journal of Quantitative Economics and the Indian Economic and Social History Review seem to

${ }^{13}$ Intercept was forced to be zero. Smaller the $\beta$, the author concentration will be higher.

${ }^{14}$ We take absolute value of $\beta$.

15 For evidence on computer science literature, see Subramanyam (1979), and for the same on finance literature, Chung and Cox (1990).

161 for specialized filed and 0 for general field

17 The extent of specialization is based on the nature of the articles, which are published in these journals. 
have moderate degree of specialization. Articles in all these journals are predominantly concerned with the Indian economy. It is difficult to say how representative this sample is because the India is yet to have an institutional mechanism to enforce the scientometric standards. ${ }^{18}$ In India, there are more than 150 universities and college departments offering research graduate programmes in economics; many of them have their own journals. Most of these journals are published at irregular intervals, and they are not widely read by the professionals. However, the journals in our sample are widely subscribed by the universities. Different scholarly works on the Indian Economy have often cited these journals. A few of them have found mention in policy papers from the Reserve Bank of India and the Government of India Departments. Most Indian authors contribute to these journals, and most of the authors who publish in these journals have current affiliations to Indian institutions or happen to be their alumni.

It can be seen from Table 3 that the share of the top three institutions varies from $15 \%$ to $30 \%$. Delhi University accounts for $17.6 \%$ of the authors in the Indian Economic Review; the journal belongs to its School of Economics. Moreover, the Institute of Economic Growth, with the second largest share, has close links with Delhi University. The top three institutions constitute $28 \%$ of authors in the Indian Economic and Social History Review, and the Delhi University has the highest share. However, for the Indian Economic Journal and Journal of Quantitative Economics, the shares of the top three institutions are just half of the figure representing the Indian Economic Review.

Table 3: Share of Top Three Institutional Contributors to a Sample of Indian Journals, 2000

\begin{tabular}{|c|c|c|c|c|c|c|}
\hline Journal & Rank 1 & & Rank 2 & & Rank 3 & \\
\hline & Institution & $\%$ & Institution & $\%$ & Institution & $\%$ \\
\hline $\begin{array}{l}\text { Indian Economic } \\
\text { Review }\end{array}$ & $\begin{array}{l}\text { University of } \\
\text { Delhi }\end{array}$ & 17.6 & $\begin{array}{l}\text { Institute of } \\
\text { Economic } \\
\text { Growth, New } \\
\text { Delhi }\end{array}$ & 8.67 & $\begin{array}{l}\text { Bureau of } \\
\text { statistics } \\
\text { India }\end{array}$ & 4.18 \\
\hline $\begin{array}{l}\text { Indian Economic } \\
\text { Journal }\end{array}$ & $\begin{array}{l}\text { University of } \\
\text { Bombay }\end{array}$ & 4.56 & University of Delhi & 3.03 & & \\
\hline $\begin{array}{l}\text { Journal of } \\
\text { Quantitative } \\
\text { Economics } \\
\end{array}$ & $\begin{array}{l}\text { Indira Gandhi } \\
\text { Institute of } \\
\text { Development } \\
\text { Research } \\
\text { (IGIDR) } \\
\end{array}$ & 6.9 & $\begin{array}{l}\text { Bureau of statistics } \\
\text { India }\end{array}$ & 5.72 & $\begin{array}{l}\text { U CA } \\
\text { Riverside }\end{array}$ & 4.08 \\
\hline $\begin{array}{l}\text { Indian Economic } \\
\text { and Social History } \\
\text { Review }\end{array}$ & $\begin{array}{l}\text { University of } \\
\text { Delhi }\end{array}$ & 15.6 & $\begin{array}{l}\text { Jawaharlal Nehru } \\
\text { University, New } \\
\text { Delhi }\end{array}$ & 3.57 & & \\
\hline
\end{tabular}

${ }^{18}$ India is yet to have scientometric measures (e.g. citation) for comparing the journals and the articles. It is often found that even the basic information on the author and the discipline is not readily available. The Indian Council of Social Science Research publishes the database on abstracts. However, there is only partial coverage of the institutional affiliation of the authors. Moreover, the institutional affiliation of the authors is not provided by some journals. Some journals do not give even the JEL code of the article.

${ }^{19}$ Institutional affiliation is not given in ECONLIT (verified from Tom Coupe, the author of the database: http://homepages.ulb.ac.be/ tcoupe/ranking.html). 
Table 4 shows the distribution of authors by the number of articles in the journals in the sample during the period 1990-2002. In order to test if Lotka's Law is applicable to the journals in the present sample, we can compare the observed distribution against the distribution predicted by Lotka's Law. It can be seen from the data that the percentage of authors with just one article varies from 80 to 88 against the prediction of Lotka's Law that these authors should constitute $61 \%$ of the total, i.e., the Indian journals do not conform to Lotka's Law. However, the author distribution in the field specific Indian Journal of Agricultural Economics is the closest to Lotka's Law. This agrees with the findings of Cox and Chung (1991), who show that the Journal of Financial Economics, one of the highly specialized journals in the sample, is closest to Lotka's Law. In other words, these journals have a higher proportion of authors with more than one article than the others. On the other hand, the proportion of authors with just one article is lower in the specialized journals than in the other journals. This phenomenon calls for further research. ${ }^{20}$

Table: 4: Frequency Distribution of Authors by Number of Publications, 1990-2002

\begin{tabular}{|c|c|c|c|c|c|c|c|c|c|c|}
\hline & & \multicolumn{9}{|c|}{ Frequency Distribution in Percent ${ }^{+}$} \\
\hline & $\mathrm{N}$ & 1 & 2 & 3 & 4 & 5 & 6 & \begin{tabular}{|l|l|}
7 & \\
\end{tabular} & 8 & $>9$ \\
\hline Indian Economic Review & 178 & 84.27 & 12.36 & 1.69 & 1.69 & 0.00 & 0.00 & 0.00 & 0.00 & 0.000 .00 \\
\hline Indian Economic Journal & 673 & 84.40 & 10.40 & 3.57 & 0.74 & 0.45 & 0.00 & 0.30 & 0.00 & \begin{tabular}{|l|l|}
0.00 & 0.15 \\
\end{tabular} \\
\hline $\begin{array}{l}\text { Journal of Quantitative } \\
\text { Economics }\end{array}$ & 263 & 87.83 & 9.13 & 1.90 & 1.14 & 0.00 & 0.00 & 0.00 & 0.00 & 0.000 .00 \\
\hline $\begin{array}{l}\text { Indian Economic and Social } \\
\text { History Review }\end{array}$ & 191 & 86.91 & 10.47 & 2.09 & 0.52 & 0.00 & 0.00 & 0.00 & 0.00 & 0.000 .00 \\
\hline Indian Journal of Economics & 468 & 85.47 & 9.40 & 2.56 & 1.07 & 0.43 & 0.85 & 0.00 & 0.00 & \begin{tabular}{|l|l|}
0.00 & 0.21 \\
\end{tabular} \\
\hline $\begin{array}{l}\text { Indian Journal of Agricultural } \\
\text { Economics }\end{array}$ & 370 & 79.73 & 11.89 & 3.51 & 1.89 & 1.62 & 0.81 & 0.27 & 0.27 & 0.000 .00 \\
\hline Artha Vijnana & 277 & 82.67 & 11.91 & 2.17 & 1.44 & 1.08 & 0.00 & 0.72 & 0.00 & \begin{tabular}{|l|l|}
0.00 & 0.00 \\
\end{tabular} \\
\hline Lotka's law $^{++}$ & & 60.79 & 15.20 & 6.75 & 3.80 & 2.43 & 1.69 & 1.24 & 0.95 & \begin{tabular}{|l|l|l|}
0.75 & 6.39 \\
\end{tabular} \\
\hline
\end{tabular}

$N=$ Number of Authors.

+ Percentage of authors publishing ' $n$ ' papers.

* For the period 1990-2001

++ The proportions of authors predicted by Lotka's law.

Source: tabulated from the data compiled by authors from different journals

The conformity of the observed distribution of authors with Lotka's distribution and can be tested for each journal by conducting the chi-square goodness-of-fit test. We start with a null hypothesis that there is no difference between Lotka's and the observed distribution. The results (Table 5) report the rejection of the null hypothesis for all the

${ }^{20} \mathrm{It}$ is quite likely that an author with only one article is younger than one with multiple articles (see Lovell (1973) for a discussion on the demographic aspects of the knowledge production). One likely hypothesis is that younger authors in economics profession have lesser participation in the specialized journals. However, an enquiry on this requires data on the role youth have in different specializations. 
journals. Moreover, Cox and Chung (1991) report the rejection of the null hypothesis for 18 out of 20 journals. ${ }^{21}$

Table 5: Indian Economics Journals-Using the Generalised Lotka's Law to Test Author Concentration, 1999-2000

\begin{tabular}{|l|l|l|l|l|l|}
\hline & $\begin{array}{l}\text { Chi-Square } \\
\text { Statistics for } \\
\text { Lotka's Law }\end{array}$ & \multicolumn{4}{l|}{ Author Concentration } \\
\hline & $\chi^{2}$ & $\beta$ & $t$ & $F$ & $R^{2}$ \\
\hline Indian Economic Review & $38.52^{*+}$ & $-3.06^{*}$ & -14.9 & 224 & 0.98 \\
\hline Indian Economic Journal & $137.11^{*+}$ & $-3.1^{*}$ & -32.18 & 1035 & 0.99 \\
\hline Journal of Quantitative Economics & $70.65^{*+}$ & $-3.27^{*}$ & -35.15 & 1235 & 0.99 \\
\hline $\begin{array}{l}\text { Indian Economic and Social History } \\
\text { Review }\end{array}$ & $49.26^{*+}$ & $-3.5^{*}$ & -27.35 & 748 & 0.99 \\
\hline Indian Journal of Economics & $102^{*+}$ & $-2.86^{*}$ & -22.19 & 492.4 & 0.99 \\
\hline Indian Journal of Agricultural Economics & $43.86^{*+}$ & $-2.7^{*}$ & -43.04 & 1852 & 0.99 \\
\hline Artha Vijnana & $48.52^{*+}$ & $-2.72^{*}$ & -21.31 & 453 & 0.99 \\
\hline
\end{tabular}

* Statistically significant at the one per cent.

+ Rejection of the Null Hypothesis of the prevalence of Lotka's Law

The concentration measure $\beta$ ranges from 2.7 to 3.5 (Table 5). ${ }^{22}$ All coefficients are statistically significant at the one per cent level. The Indian Journal of Agricultural Economics reports the highest author concentration, and the Indian Economic and Social History Review has the lowest concentration. The institutional concentration with respect to this journal (i.e. share of top three institutions) is the second highest. This observation is consistent with the findings by Cox and Chung (1991), who observe:

It is interesting to note that journals which have been known as exhibiting higher institutional concentrations among their authors do not exhibit higher individual concentrations among their contributors. ( $\mathrm{p} 745)$

In other words, this result suggests that the competition for publication is limited to the authors from the top institutions. Another important observation from table 5 is that the Indian Journal of Agricultural Economics, the most specialized journal in the sample, shows the highest author concentration. Further, Cox and Chung (1990) also show a similar finding. They find a significant relation between the degree of specialization and the degree of author concentration. They infer that the higher the degree of specialization, the higher will be the degree of author concentration.

It is interesting to note that the degree of author concentration in Indian journals is, in general, considerably lower than that of the leading journals that Cox and Chung (1991) report upon. (Table 6). However, to generalize the relations, which are

21 The null hypothesis is accepted for the Journal of Financial Economics and the Brookings Papers on Economic Activity.

${ }^{22} \beta$, according to Lotka's law, is 2 . But, no journal in our sample reports 2 . 
Bino Paul G. D. , Subash S. , A. Ramanathan, Concentration in Knowledge Output

discussed in this paper requires more rigorous approach in terms of sample and measurement.

Table 6: Author Concentration: A comparison between Indian Journals and Cox and Chung (1991)

\begin{tabular}{|l|c|}
\hline Journal & $\beta$ \\
\hline Author Concentration among Indian Journals & \\
\hline Indian Economic Review & -3.06 \\
\hline Indian Economic Journal & -3.1 \\
\hline Journal of Quantitative Economics & -3.27 \\
\hline Indian Economic and Social History Review & -3.5 \\
\hline Indian Journal of Economics & -2.86 \\
\hline Indian Journal of Agricultural Economics & -2.7 \\
\hline Artha Vijnana & -2.72 \\
\hline Estimates by Cox and Chung (1991) & \\
\hline American Economic Review & -2.31 \\
\hline Journal of Political Economy & -2.66 \\
\hline Econometrica & -2.35 \\
\hline Journal of Monetary Economics & -2.5 \\
\hline Journal of Economic Theory & -2.46 \\
\hline Review of Economic Studies & -2.58 \\
\hline International Economic Review & -2.86 \\
\hline Bell Journal of Economics & -2.74 \\
\hline Journal of Finance & -2.23 \\
\hline Journal of Econometrics & -2.47 \\
\hline Scandinavian Journal of Economics & -2.69 \\
\hline Brookings Papers on Economic Activity & -2.04 \\
\hline Journal of Public Economics & -2.56 \\
\hline Journal of Financial Economics & -2.2 \\
\hline Review of Economics and Statistics & -2.95 \\
\hline Journal of the American Statistical Association & -2.75 \\
\hline Quarterly Journal of Economics & -3.11 \\
\hline Journal of Human Resources & -2.59 \\
\hline Journal of Economic Literature & -2.59 \\
\hline Economic Journal & -2.84 \\
\hline Sour & \\
\hline
\end{tabular}

Source: Table 5 and Cox and Chung (1991, p. 743)

We are doubtful whether any scholarly work has tested Lotka's Law in Indian economics journals in India before. ${ }^{23}$ However, we found a recent paper, which tests the prevalence of Lotka's Law in Indian Physics during 1800-1945 (Gupta et al., 1998). The paper reports that the Lotka's distribution is applicable to the initial stages of the discipline's growth (i.e. during 1800-1920). It is shown in the paper that for the remaining period, 1920-1945, the period in which Indian physics exhibited major growth, the data do not fit Lotka's Law. An important limitation of the study is that only aggregate data are tested, not that for individual journals.

${ }^{23}$ We surveyed not only economics journals but library science journals too. 


\section{Publication Process}

A major issue, which is related to the publication process, which is worth considering, is the growing publication lag. Ellison (2002a), Trivedi (1993), and Mason et al. (1992) address the issues related to the publication lag. These papers report the publication lag at different points of time. Ellison (2002b) proposes the $q-r$ theory and tries to explain the phenomenon of the publication lag. This theory specifies that two characteristics of an article determine whether it is accepted for publication, the quality of its ideas, $q$, and the polish of the article, $r$. According to his theory, $r$ is given more weight than $q$ by the editors and referees of the journals. As a result, more time is spent on polishing the article so that the chance of its acceptance by the journal is improved. A likely consequence of the lag, according to Ellison, is that other scholars, who come up later with similar ideas, may get their article published earlier in another journal, thereby robbing the credit for a new idea.

Gans and Shepherd (1994) cite a few instances of the rejection of papers, which became path-breaking works in economics (table A4, Appendix). Referees and editors, according to Gans and Shepherd, tend to show insensitivity to the novel ideas, which may even change the scope of the discipline. George Akerlof's seminal contribution, 'The Market for Lemons: Quality, Uncertainty and the Market Mechanism', is a remarkable case of rejection. Gans and Shepherd narrate Akerlof's ordeal (1994):

Before the Quarterly Journal of Economics finally accepted Akerlof's paper four years after he first sought to publish it, three journals called it a lemon... The rejections discouraged Akerlof. Akerlof believes that journal editors refused the article both because they feared the introduction into economics of informational considerations and because they disliked the article's readable style. (pp. 171)

Gans and Shepherd (1994) cite a number of such cases. It can be observed from Table A4 (Appendix) that all the authors of these rejected papers are affiliated to top institutions. One would like to believe that the author's efforts help her to attain the publication rather than she gets the support from the institutions. Nevertheless, the literature shows instances of the institution finally coming to the rescue of the author. Paul Krugman's experience can be a good case of institutional intervention helping the author. Krugman sent his article 'Increasing Returns, Monopolistic Competition, and International trade' to the Quarterly Journal of Economics. He got the rejection letter after eight months. Finally, the paper was published in the Journal of International Economics (JIE). Jagdish Bhagwati, the editor of JIE at that point of time, vetoed two referee's objection and accepted Krugman's work. Gans and Shepherd (1994) quote Bhagwati :

I published it myself despite two adverse referee reports by very distinguished experts on the theory of increasing returns! It did take some courage and also a strong sense of the importance of the paper for me to do so, since Krugman had been my student and normally I would lean over backwards not to publish my own students' work. ( $p$ 171)

Here, Bhagwati's action can be construed as an institutional intervention, since his role as a teacher is an institutional one. Gans and Shepherd (1994) have a few more such cases. 
It is doubtful if the effort and quality get more weight than the factors such as the luck and compliance with the norms when the journals accept the papers for the publication.

\section{Conclusion}

A large number of journals (out of 704) show the high degrees of field, geographic, and institutional concentration. The author concentration is measured for seven journals, which are published in India. There are similarities between our findings and Cox and Chung (1991); for instance, the relation between specialization and degree of concentration, which emerge from the discussion in this paper, is also a major finding by Cox and Chung. Furthermore, the tests of Lotka's Law show results which are similar to those of Cox and Chung. An important cue, drawn from the literature, is that the competition for the publication in the prestigious journals is largely confined to the authors from institutions of repute; this is also applicable to leading Indian journals such as the Indian Economic Review.

Given the high degrees of concentration, the publication lag is a major issue that emerges from the literature on the publication process; this has been evolving as a norm, which often affects decision-making in journals (Ellison, 2000b). This evolution has a few consequences, which may even affect the growth of the discipline. Ellison's theory that polish replaces the quality of the content of economics journals is quite relevant in this context; this theory shows similarities with the theory of institutional oligopoly (Hodgson and Rothman, 1999). For instance, Hodgson and Rothman argue that the lock-in that prevails in the profession may affect the flow of innovative ideas into Economics. Future research may look into the relation between degree of concentration and scientific progress in economics.

\section{References}

Beed C., Kane O. (1991), 'What is the Critique of the Mathematization of Economics', Kyklos,.44, 581-612.

Chung K. H., Cox R. A. K (1990), 'Patterns of Productivity in the Finance Literature: A Study of the Bibliometric Distributions', Journal of Finance, 45, 301-309.

Cleary F. R.,. Edwards D. J (1960), 'The Origins of the Contributors to the A. E. R. During the Fifties', American Economic Review, 50, 1011-1014.

Coupe T. (2001), 'Revealed Performances: World Wide Ranking of Economics Departments and Economists, 1969-2000', downloadable at <http://homepages.ulb.ac.be/ tcoupe/ranking.html>

Cox R. A. K, Chung K. H. (1991), 'Patterns of research Output and Author Concentration in economics Literature', Review of Economics and Statistics, 73, 740-747.

Davis P., Papanek G. F.. (1984), 'Faculty Ratings of Major Economics Departments by Citation', American Economic Review, 74, 225-230.

Dusansky R., Vernon C. J. (1998), 'Ranking of US Economics Departments', Journal Economic Perspectives, 12, 157-70.

Ellison G. (2002a), 'The Slowdown of economics Publishing Process', Journal of Political Economy, 110, 947-993

Ellison G. (2002b), 'Evolving Standards for Academic Publishing: A q-r Theory', Journal of Political Economy, 110, 994-1034 
Gans J.S., Shepherd G.B.(1994), 'How Are the Mighty Fallen: Rejected Classic Articles by Leading Economists', Journal of Economic Perspectives, 8, 165-179.

Graves P. E.,. Marchand J. R, Thompson G.(1982), 'Economics Departmental Ranking: Research Incentives, Constraints and Efficiency', American Economic Review, 72, 1131-1141.

Gupta B. M., Sharma L., Kumar S. (1998), 'Literature Growth and Author Productivity in Indian Physics’, Information Processing \& Management, 34, 121- 131

Hirsch B. T., Randall A., Brooks J., Moore J. B. (1984), 'Economics Departmental Rankings: Comment', American Economic Review, 74, 822-26.

Hirschman A. O. (1964), 'The Paternity of an Index', American Economic Review, 56, 761-762.

Hodgson G. M., Rothman H. (1999), 'The Editors and Authors of Economics Journals: A Case of Institutional Oligopoly', Economic Journal, 109, 165-186.

Hogan T. D. (1984), 'Economics Departmental Rankings: Comment', American Economic Review, 74, 827-33.

Ingwersen P., Larsen B., Noyons E. (2001), 'Mapping National Research Profiles in Social Science Disciplines', Journal of Documentation, 57, 715-740.

Kalaitzidakis P., Theofanis M., Thanasis S. (1999), 'European Economics: An Analysis Based on Publications in the Core Journals', European Economic Review, 43, 1150-1168.

Kocher M. G., Sutter M. (2001), 'The Institutional Concentration of Authors in Top Journals of Economics During the Last Two Decades', Economic Journal, 111, 405-421.

Laband D., Piette M. (1994), 'Favouritism versus Search for Good Papers: Empirical Evidence Regarding the Behaviour of Journal editors', Journal of Political Economy, 102, 194-203.

Liebowitz, S. J., J. P. Palmer (1988), 'Assessing Assessments of Economics Departments', Quarterly Review of Economics and Business, 28, 88-113.

Lotka A. J (1926), 'The Frequency Distribution of Scientific Productivity', Journal of the Washington Academy of Sciences, 16, 317-23.

Lovell M. C. (1973), 'The Production of Economic Literature: An Interpretation', Journal of Economic Literature, 11, 27-55.

Mason P. M., Steagall J. W., Fabritius, M. M. (1992), 'Publication delays in Economics: What to do about them', Applied Economics, 24, 859-874.

Scott L., Mitias P. (1996), 'Trends in Rankings of Economics Departments in the US: An Update', Economic Inquiry, 34, 378-400.

Siegfried J., Stock W. (1999), 'The Labour Market for New Ph D Economists', Journal of Economic Perspectives, 13, 115-134.

Siegfried J. (1972), 'The Publishing of Economic Papers and Its Impact on Graduate Faculty Ratings, 1960-1969', Journal of Economic Literature, 10, 31-49.

Stigler G. J., Stigler S. M., Friedland C. (1995), 'The Journals of Economics', Journal of Political Economy, 103, 331-359

Subramanyam K. (1979), 'Lotka's Law and Computer Science Literature', IEEE Transactions on Professional Communication, 22, 187-189.

Thursby J. G. (2000), 'What do We Say About Ourselves and What does it Mean? Yet Another Look at Economics Department Research', Journal of Economic Literature, 38, 383-404.

Trivedi P. K. (1993), 'An Analysis of Publication Lags in Econometrics', Journal of Applied Econometrics, 8, 93-100.

U.S. Department of Justice and Federal Trade Commission (1997), Merger Guidelines downloadable at <http://www.usdoj.gov/atr/public/guidelines/horiz_book/toc.html>

Yotopoulos, P. (1961), 'Institutional Affiliation of the Contributors to Three Professional Journals', American Economic Review, 51, 665-670. 
Bino Paul G. D. , Subash S. , A. Ramanathan, Concentration in Knowledge Output

\section{Appendix}

Table A1: An Outline of Literature on Institutional and Regional Concentration in Economics Journals

\begin{tabular}{|c|c|c|c|}
\hline \multicolumn{4}{|c|}{ Institutional Concentration } \\
\hline $\begin{array}{l}\text { Sl. } \\
\text { No }\end{array}$ & Authors & Methodology & Top Ten Institutions \\
\hline 1. & $\begin{array}{l}\text { Cleary and Edward } \\
(1960)\end{array}$ & $\begin{array}{l}\text { Number of pages contributed } \\
\text { to American Economic } \\
\text { Review during 1950-1959 (100 } \\
\text { pages and above) }\end{array}$ & $\begin{array}{l}\text { UC Berkeley, MIT, } \\
\text { Stanford, Chicago, U. } \\
\text { Michigan, Federal } \\
\text { Reserve Systems, John } \\
\text { Hopkins, UCLA, } \\
\text { Harvard, Yale }\end{array}$ \\
\hline 2. & Yotopoulos (1961) & $\begin{array}{l}\text { Number of pages contributed } \\
\text { to American Economic } \\
\text { Review, Quarterly Journal of } \\
\text { Economics and Journal of } \\
\text { Political Economy (combined) } \\
\text { during 1950-1959 ( } 300 \text { pages } \\
\text { and above) }\end{array}$ & $\begin{array}{l}\text { Harvard, Chicago, UC } \\
\text { Berkeley, MIT, Stanford, } \\
\text { Columbia, U. Michigan, } \\
\text { Wisconsin-Madison, } \\
\text { Federal Govt, Carnegie- } \\
\text { Mellon }\end{array}$ \\
\hline 3. & Siegfried (1972) & $\begin{array}{l}\text { Number of pages contributed } \\
\text { to American Economic } \\
\text { Review, Quarterly Journal of } \\
\text { Economics and Journal of } \\
\text { Political Economy (combined) } \\
\text { during 1960-1969 (1 \% and } \\
\text { above) }\end{array}$ & $\begin{array}{l}\text { Chicago, Harvard, MIT, } \\
\text { Yale, UC Berkeley, Penn, } \\
\text { Stanford, Princeton, } \\
\text { Carnegie-Mellon, } \\
\text { Columbia }\end{array}$ \\
\hline 4. & Lovell (1973) & $\begin{array}{l}\text { Ph D Origin of cited authors } \\
\text { in American Economic } \\
\text { Review, Quarterly Journal of } \\
\text { Economics, Journal of } \\
\text { Political Economy and } \\
\text { Econometrica (combined) }\end{array}$ & $\begin{array}{l}\text { Harvard, Chicago, } \\
\text { Columbia, Yale, } \\
\text { Princeton, U. Michigan, } \\
\text { MIT, UC-Berkeley, } \\
\text { Wisconsin-Madison, } \\
\text { John Hopkins }\end{array}$ \\
\hline 5. & $\begin{array}{l}\text { Graves, Marchand } \\
\text { and } \\
\text { Thompson(1982) }\end{array}$ & $\begin{array}{l}\text { a. AER equivalent sized pages } \\
\text { in the top } 24 \text { journals (1974- } \\
78 \text { ) } \\
\text { b. Pages per Economics } \\
\text { department faculty in the top } \\
24 \text { journals (1974-78), } \\
240 \text { institutions }\end{array}$ & $\begin{array}{l}\text { Chicago, Harvard, } \\
\text { Stanford, Wisconsin- } \\
\text { Madison, Penn, MIT, } \\
\text { Yale, UCLA, UC } \\
\text { Berkeley, Princeton }\end{array}$ \\
\hline 6. & $\begin{array}{l}\text { Davis and Papanek } \\
\text { (1984) }\end{array}$ & $\begin{array}{l}\text { a. Total Number of Citations } \\
\text { b. Rank by mean number of } \\
\text { citation } \\
\text { (a, b for } 122 \text { institutions) } \\
\text { c. Number of citation } \\
\text { controlling for age and } \\
\text { dispersion } \\
\text { d. Rank controlling only for }\end{array}$ & $\begin{array}{l}\text { Chicago, Harvard, MIT, } \\
\text { Stanford, Princeton, } \\
\text { Yale, Penn, Wisconsin- } \\
\text { Madison, Columbia, UC } \\
\text { Berkeley }\end{array}$ \\
\hline
\end{tabular}




\begin{tabular}{|c|c|c|c|}
\hline & & $\begin{array}{l}\text { e. Rank controlling for } \\
\text { dispersion (c, d, e for } 40 \\
\text { institutions) }\end{array}$ & \\
\hline 7. & Hirsch et al. (1984) & $\begin{array}{l}\text { Total pages (1978-83) } \\
240 \text { institutions } \\
\text { (Methodology of Greaves, } \\
\text { Marchand and Thompson } \\
(1982) \text { ) }\end{array}$ & $\begin{array}{l}\text { Chicago, Harvard, } \\
\text { Stanford, London School } \\
\text { of Economics, Penn, } \\
\text { Yale, Northwestern, } \\
\text { MIT, Wisconsin- } \\
\text { Madison, UC Berkeley }\end{array}$ \\
\hline 8. & Hogan (1984) & $\begin{array}{l}\text { a. Total Pages by current } \\
\text { faculty } \\
\text { b. Total Pages by listed } \\
\text { affiliation } \\
\text { ( } 50 \text { institutions) }\end{array}$ & $\begin{array}{l}\text { Harvard, Princeton, MIT, } \\
\text { Yale, Chicago, Stanford, } \\
\text { Wisconsin-Madison, } \\
\text { Minnesota, UCLA, Penn }\end{array}$ \\
\hline 9. & $\begin{array}{l}\text { Liebowitz and } \\
\text { Palmer (1988) }\end{array}$ & $\begin{array}{l}\text { a. Citation based on various } \\
\text { weighting schemes } \\
\text { b. Citation based on } \\
\text { publications } \\
\text { ( } 60 \text { institutions) }\end{array}$ & $\begin{array}{l}\text { Chicago, MIT, Harvard, } \\
\text { Stanford, Princeton, } \\
\text { UCLA, Minnesota, Yale, } \\
\text { Columbia, Northwestern }\end{array}$ \\
\hline 10. & $\begin{array}{l}\text { Scott and Mitias } \\
\text { (1996) }\end{array}$ & $\begin{array}{l}\text { a. Ranking based on flow of } \\
\text { pages 1984-93 } \\
\text { ( } 240 \text { institutions) } \\
\text { b. Departmental Stock } \\
\text { Ranking of Pages in top } 36 \\
\text { journals (80 institutions) 1984- } \\
93 \\
\text { (Methodology of Greaves, } \\
\text { Marchand and Thompson } \\
\text { (1982) }\end{array}$ & $\begin{array}{l}\text { Harvard, Chicago, Penn, } \\
\text { MIT, Northwestern, } \\
\text { Stanford, Princeton, U. } \\
\text { Michigan, UC Berkeley, } \\
\text { UCLA }\end{array}$ \\
\hline 11. & $\begin{array}{l}\text { Dusansky and } \\
\text { Vernon (1998) }\end{array}$ & $\begin{array}{l}\text { a. Aggregate adjusted pages } \\
\text { b. Adjusted Pages per faculty } \\
\text { (80 institutions) }\end{array}$ & $\begin{array}{l}\text { Princeton, Harvard, MIT, } \\
\text { Penn, Northwestern, } \\
\text { New York U, Boston, } \\
\text { Yale, Stanford, U C San } \\
\text { Diego }\end{array}$ \\
\hline 12. & $\begin{array}{l}\text { Kalaitzidakis et al. } \\
\text { (1999) }\end{array}$ & $\begin{array}{l}\text { a. Ranking Based on total } \\
\text { AER standardized pages } \\
\text { b. Ranking based on total } \\
\text { unadjusted pages } \\
\text { (198 institutions) }\end{array}$ & $\begin{array}{l}\text { Chicago, Harvard, MIT, } \\
\text { Northwestern, Princeton, } \\
\text { Penn, Stanford, Yale, } \\
\text { Columbia, UC-Berkeley }\end{array}$ \\
\hline 13 & $\begin{array}{l}\text { Hodgson and } \\
\text { Rothman (1999) }\end{array}$ & $\begin{array}{l}\text { a. Institutional origin (Ph D } \\
\text { School) and Current affiliation } \\
\text { of authors } \\
\text { b. Institutional origin (Ph D } \\
\text { School) and Current affiliation } \\
\text { of Editors } \\
\text { ( } 30 \text { journals) }\end{array}$ & $\begin{array}{l}\text { Harvard, MIT, Chicago, } \\
\text { Stanford, U. Michigan, } \\
\text { UC Berkeley, Princeton, } \\
\text { Yale, Wisconsin- } \\
\text { Madison, Columbia }\end{array}$ \\
\hline
\end{tabular}


Bino Paul G. D. , Subash S. , A. Ramanathan, Concentration in Knowledge Output

\begin{tabular}{|l|l|l|l|}
\hline 13. & Thursby (2000) & $\begin{array}{l}\text { Performance perception } \\
(104) \text { institutions }\end{array}$ & $\begin{array}{l}\text { Harvard, Stanford, } \\
\text { Chicago, MIT, Princeton, } \\
\text { Yale, UC-Berkeley, Penn, } \\
\text { Northwestern, Minnesota }\end{array}$ \\
\hline 14. & Coupe (2001) & $\begin{array}{l}\text { Ranking on the basis of } \\
\text { citation and publication counts } \\
(200 \text { institutions) 1969-2000 }\end{array}$ & $\begin{array}{l}\text { Harvard, Chicago, Penn, } \\
\text { Stanford, MIT, UC- } \\
\text { Berkeley, Northwestern, } \\
\text { Yale, U. Michigan, } \\
\text { Columbia }\end{array}$ \\
\hline Regional Concentration & $\begin{array}{l}\text { Hodgson and } \\
\text { Rothman (1999) }\end{array}$ & $\begin{array}{l}\text { Regional Distribution of } \\
\text { Institutional origin (Ph D } \\
\text { School) and Current affiliation } \\
\text { of authors } \\
\text { (30 journals) and Editors }\end{array}$ & $\begin{array}{l}\text { U.S.A 's share is in the } \\
\text { range of 65-83\% }\end{array}$ \\
\hline 2 & $\begin{array}{l}\text { Kocher and Sutter } \\
\text { (2001) }\end{array}$ & $\begin{array}{l}\text { Regional Distribution of } \\
\text { Institutional origin (Ph D } \\
\text { School) and Current affiliation } \\
\text { of authors } \\
\text { (15 journals, 1977-1997) }\end{array}$ & $\begin{array}{l}\text { U.S.A 's share is in the } \\
\text { range of 65-85\% }\end{array}$ \\
\hline
\end{tabular}

Table A2: The Distribution of Journals over the Sub fields [2000]

\begin{tabular}{|l|l|l|l|}
\hline JEL Code & Sub field & $\begin{array}{l}\text { Number of } \\
\text { Journals }\end{array}$ & Percentage \\
\hline A & General Economics and Teaching & 5 & 0.71 \\
\hline B & $\begin{array}{l}\text { Methodology and History of Economic } \\
\text { Thought }\end{array}$ & 19 & 2.70 \\
\hline C & Mathematical and Quantitative Methods & 25 & 3.55 \\
\hline D & Microeconomics & 51 & 7.24 \\
\hline E & Macroeconomics and Monetary Economics & 84 & 11.93 \\
\hline F & International Economics & 63 & 8.95 \\
\hline G & Financial Economics & 76 & 10.80 \\
\hline H & Public Economics & 16 & 2.27 \\
\hline I & Health, Education and Welfare & 16 & 2.27 \\
\hline J & Labour and Demographic Economics & 60 & 8.52 \\
\hline K & Law and Economics & 10 & 1.42 \\
\hline L & Industrial Organization & 39 & 5.54 \\
\hline M & $\begin{array}{l}\text { Business Administration and Business } \\
\text { Economics }\end{array}$ & 17 & 2.41 \\
\hline $\mathrm{N}$ & Economic History & 19 & 2.70 \\
\hline O & $\begin{array}{l}\text { Economic Development, Technical Change and } \\
\text { Growth }\end{array}$ & 87 & 12.36 \\
\hline P & Economic systems & 31 & 4.40 \\
\hline Q & Agricultural and Natural Resources & 47 & 6.68 \\
\hline R & Urban, Rural and Regional Economics & 37 & 5.26 \\
\hline Z & Other Topics & 2 & 0.28 \\
\hline & Total & 704 & 100 \\
\hline Sour Computed from & & \\
\hline
\end{tabular}

Source: Computed from <http:/ / homepages.ulb.ac.be/ tcoupe/ ranking.html> 
Table A3: Fitting Lotka's Law for different values of $\beta$ (assuming $a_{1}=100$ )

\begin{tabular}{|l|l|l|l|l|}
\hline Number of Papers $(\mathrm{n})$ & $\mathrm{a}_{1}$ & $\mathrm{a}_{\mathrm{n}}(\beta=1)$ & $\mathrm{a}_{\mathrm{n}}(\beta=2)$ & $\mathrm{a}_{\mathrm{n}}(\beta=3)$ \\
\hline 1.00 & 100 & 100.00 & 100.00 & 100.00 \\
\hline 2.00 & 100 & 50.00 & 25.00 & 12.50 \\
\hline 3.00 & 100 & 33.33 & 11.11 & 3.70 \\
\hline 4.00 & 100 & 25.00 & 6.25 & 1.56 \\
\hline 5.00 & 100 & 20.00 & 4.00 & 0.80 \\
\hline 6.00 & 100 & 16.67 & 2.78 & 0.46 \\
\hline 7.00 & 100 & 14.29 & 2.04 & 0.29 \\
\hline 8.00 & 100 & 12.50 & 1.56 & 0.20 \\
\hline 9.00 & 100 & 11.11 & 1.23 & 0.14 \\
\hline 10.00 & 100 & 10.00 & 1.00 & 0.10 \\
\hline
\end{tabular}

Note: $a_{n}=\frac{a_{1}}{n^{\beta}}$

Source: Hypothetical Data

Table A4: Rejected Papers*

\begin{tabular}{|l|l|}
\hline Authors Name & Rejected Paper: Title \\
\hline Akerlof, George & The Market for Lemons \\
\hline Arthur W Brain & $\begin{array}{l}\text { Competing Technologies, Increasing Returns, and Lock-In by } \\
\text { Historical Events }\end{array}$ \\
\hline Becker Gary S & Competition and Democracy \\
\hline Becker Gary S & A Theory of the Allocation of Time \\
\hline Bhagwati, Jagdish & Immiserizing Growth: A Geometrical Note \\
\hline $\begin{array}{l}\text { Black, Fischer, and Myron } \\
\text { Scholes }\end{array}$ & The Pricing of Options and Corporate Liabilities \\
\hline Buchanan, James M & External and Internal Public Debt \\
\hline Chichilinisky, Graciela & $\begin{array}{l}\text { Basic Goods, Commodity Transfers and the New International } \\
\text { Economic Order }\end{array}$ \\
\hline Corden, W. Max & The Structure of a tariff System and the Effective Protective Rate \\
\hline Debreu, Gerard & Numerical Representations of Technological change \\
\hline $\begin{array}{l}\text { Fisher, Franklin M, Zvi } \\
\text { Griliches, Carl Kaysen }\end{array}$ & The Costs of Automobile Model Changes Since 1949 \\
\hline Friedman Milton & $\begin{array}{l}\text { Professor Pigou's Method for Measuring Elasticities of Demand from } \\
\text { Budgetary Data }\end{array}$ \\
\hline Harrod, Roy & The Law Decreasing Costs \\
\hline Hotelling, Harold & Economics of Exhaustible Resources \\
\hline Jonung, Lars & $\begin{array}{l}\text { Ricardo on Machinery and the present Unemployment: An } \\
\text { Unpublished Manuscript by Knut Wicksell }\end{array}$ \\
\hline Kalecki, Michal & A Theorem on Technical Progress \\
\hline Krugman, Paul & $\begin{array}{l}\text { Increasing Returns, Monopolistic Competition, and International } \\
\text { Trade }\end{array}$ \\
\hline Krugman, Paul & Target Zones and Exchange Rate Dynamics \\
\hline Lazear Edward P and Sherwin & Rank-Order Tournaments as Optimal Labour Contracts \\
\hline
\end{tabular}


Bino Paul G. D. , Subash S. , A. Ramanathan, Concentration in Knowledge Output

\begin{tabular}{|l|l|}
\hline Rosen & \\
\hline Lucas Robert E & Expectations and the Neutrality of Money \\
\hline $\begin{array}{l}\text { May, Robert, and John } \\
\text { Beddington }\end{array}$ & Nonlinear Difference Equations: Stable Points, Stable Cycles, Chaos \\
\hline May, Robert & Simple Mathematical Models with Very Complicated Dynamics \\
\hline Modigliani Franco & $\begin{array}{l}\text { Fluctuations in the Savings-Income Ratio: A Problem in Economic } \\
\text { Forecasting }\end{array}$ \\
\hline Ohlin, Bertil & Interregional and International Trade \\
\hline Scitovsky, Tibor & A Reconsideration of the Theory of Tariffs \\
\hline Sharpe, William & $\begin{array}{l}\text { Capital Asset Prices: A Theory of Equilibrium Under Conditions of } \\
\text { Risk }\end{array}$ \\
\hline $\begin{array}{l}\text { Stolper, Wolfgang, and } \\
\text { Samuelson, Paul A. }\end{array}$ & Protection and Real Wages \\
\\
Fhese articles were later published in other journals. \\
Source: Gans and Shepherd (1994 $p$ 167)
\end{tabular}

